\title{
Evaluation of E-Service Quality through Customer Satisfaction (a Case Study of FBR E-Taxation)
}

\author{
Madad Ali, Fahad Asmi*, Md. Mashiur Rahman, Naveed Malik, Muhammad Salman Ahmad \\ School of Public Affairs, University of Science and Technology of China, Hefei, China \\ Email: ${ }^{\star}$ fasmie@mail.ustc.edu.cn
}

How to cite this paper: Ali, M., Asmi, F., Rahman, Md.M., Malik, N. and Ahmad, M.S. (2017) Evaluation of E-Service Quality through Customer Satisfaction (a Case Study of FBR E-Taxation). Open Journal of Social Sciences, 5, 175-195.

https://doi.org/10.4236/jss.2017.59013

Received: August 16, 2017

Accepted: September 18, 2017

Published: September 21, 2017

Copyright (c) 2017 by authors and Scientific Research Publishing Inc. This work is licensed under the Creative Commons Attribution International License (CC BY 4.0).

http://creativecommons.org/licenses/by/4.0/

(c) (i) Open Access

\begin{abstract}
This study developed the research model to analyze the relationship between suggested service quality dimensions with customer satisfaction and customer reuse intention. The sample count of 188 from FBR's e-taxation/e-filling users was used to examine the study model. In this study, the Exploratory factor analysis EFA used to observe the validity and reliability of the measurement model. The statistical method i.e. regression model has been used to check the research model significance relationship among various variable. Statistical result of current research shows that the service quality dimensions namely responsiveness, reliability and trust has significantly related to customer satisfaction whereas empathy has found insignificant. Practical implication of the current investigations suggests to improve the service quality which can progress customer's satisfaction as well the intention of use. The findings of this study provide valuable information to administrative authorities of e-government development regarding e-taxation, as well as for future researchers and projects in domain of e-services.
\end{abstract}

\section{Keywords}

E-Taxation, Pakistan, Trust, Responsiveness, Empathy, Reliability, Customer Satisfaction, Intention to Use

\section{Introduction}

The effect of new advancement in the field of technology regarding public management is on the climb. The internet plays a vital role in this new technological era as the governments nowadays globally focuses on innovatively implementing citizens' services. This phenomenon has given rise and highlighted various 
citizens-related challenges. It includes the citizen's interaction with available e-government services. With the sudden increase in self-administrated e-services for citizens, the current fashion of research is headed forward to identify the factors accepting the quality of service in the provision of e-government facilities for the end-users which is foremost an important tool for encouraging citizens' acceptance and usage [1] [2].

In the recent years e-service quality has received researchers' considerations and attentions due to its importance [3]. Basically the notion of e-service excellence is different and complex from perception of traditional public service excellence. E-service attractiveness can be categorized as the key contributing factors to the accomplishment or success of online web based adoption [4] [5]. As stated by Lee and Lin (2005) numerous online institutions wilt because of poor e-service quality management. E-service quality can be differentiated as comprehensive consumer appraisal and assessments about the excellence of e-service provision in the implicit marketplace are available [6].

Electronic service of public services, particularly the accessibility of various forms and offering services, and the alternative of electronically submitting them, gives an effective way to save time and money for people [7]. Innovations now makes it conceivable to customize a website to a point where conveyance of services could be custom-made to meet the particular needs of an individual, in this manner expanding the fulfillment of consumers from public sector services [8]. Research has frequently revisited to study e-government driven service quality as how much an e-government website encourages the able conveyance of effective e-services to facilitate users, agencies and businesses in achieving their governmental transactions [9]. However, the nature of e-government driven services can assume a huge part in enhancing e-government efficiency, and also expanding users' satisfactions.

Achievement of a service acceptance based on the high quality association with end-users which determines consumer loyalty and satisfaction [10]. Consumer loyalty is characterized as "post-utilization assessment of how well a store or item meets or surpasses client desires" [11]. Chang and colleagues (2009) stated that user's satisfaction is about affecting positive feelings in the users, after consuming a service [12]. Research has indicated frequently that by giving service by maintaining quality impacts governmental better performance [13]. Moreover, service quality and consumer loyalty were observed to be identified with consumer satisfaction through repurchase and revisit intentions [14]. The current study adopted four service quality dimensions for measuring the e-service quality and their effects on customer's satisfaction (responsiveness, empathy, reliability and trust) which recommended by different previous researchers.

E-Service in the case of taxation and e-filling is basically an approach to serve your archives utilizing web and taxes online system. It reduces time and saves a lot of money over traditional techniques. E-filing is an electronic services facility delivered by the government institutions to the citizens to record income tax 
assessment forms/proclamations. In the case of Pakistan, the most of the innovation adoption began in mid-2000; its nuts and bolts point was to help public sector institutions in increase pace of service delivery, effectiveness and responsiveness with the utilization of Information and Communication Technology. It centered Infrastructure advancement of government organizations and accordingly facilitating general citizens in utilizing services of various government organizations effectively. Expanding the e-filing system for FBR was additionally a highly preferred and significant projects; when in December 2005 the Central Board of Revenue (CBR), the tax authority formally began permitting e-filing of sales tax assessment and government extract proceeds by recording private and government organizations. Moreover, it is serving with the human resource of approximately 1500 and serving in thousands of citizens to utilize the service facility. Currently with the assistance of e-filling system and different approaches FBR has effectively expanded the assessment and expansion of the tax net to extraordinary ranges. Significant Functions are performed by FBR by help of E-filing: Issuance of national tax number (NTN) and sales tax impose numbers, Collection of Sales Tax, Income tax and property tax, Keeping record of citizens and offering it to important gatherings and issuing taxpayers citizens list all the more effortlessly and successfully [15] [16].

The purpose of the study is to find the more influencing quality parameters in the current scenario in among "responsiveness", "empathy", "reliability" and "trust" to define the satisfaction and how collectively "satisfaction", "trust" and "responsiveness" affects the decision of e-fillers for taxation in Pakistan to make the "decision regarding the reuse of the e-service".

\section{Literature}

\subsection{Responsiveness}

Responsiveness is defined as the complications faced by the customers while availing or using organizational services and the ability or response of the organization to help or motivate the customers to avoid and solve those complications [17] [18]. Responsiveness in terms of e-service is a convincing management procedure offered to the users by various means through Internet [7].

Chang and colleagues (2009) describe that awareness measures "the limit of e-retailers to give appropriate data to shoppers when an issue happens, having frameworks for dealing with returns, and giving on the web guarantees" [12]. Kim and colleagues (2006) analyze unmistakable accomplishment factors in an online store and express that buying satisfaction of the clients is one of those components fundamental for Website accomplishment [19]. Lee and Lin (2005) Imply that consumers shopping on the web are foreseeing factor that retailers should respond to their inquiries promptly [20].

Ribbink and colleagues (2004) express that online users need speedy input on inquires, yet in addition on suggestions for upgrades of the service [21]. They likewise emphasized that by having a decent part of responsiveness may positively 
affect consumer satisfaction. A few empirical studies uncovered that there is a considerable relationship between responsiveness measurement and consumer satisfaction [20]. Yang and Fang (2004) observed that there are remarkable four quality scope prompting both fulfillment and discontent, including consistency, ease of use, responsiveness and capability [22].

\subsection{Empathy}

Empathy concerns with users' attitudes that the online portal is giving them individualized consideration and it gives them best advantages on a basic level through the coordination of both delivery mechanism and service content [9]. Despite the fact that it is believed that there is no instant human interference in the implicit e-service course, while some human contacts are engaged with e-services. Realizing consumer consideration, it demonstrates empathy to consumers. Regarding the characteristics of empathy aspects it can be point out: great individual consideration, satisfactory contacts, and address grievances friendly and reliably respectful [7].

Parasuraman and colleagues (1985) in their study reveals that empathy is the caring for individual consideration and needs that the firm present to its consumer [23]. It includes giving consumers particular consideration and counseling who realize the requirements of their consumers and comfort business hours. Ananth and colleagues (2010) has directed understanding in their study on classified service sector which gives individual attention; suitable working hours; and providing personal attention to their customers; overall best convenient services and understand customer's required specific needs [24]. According to Ndubis (2006) classified consumer satisfaction can be accomplished by offering customized, adaptable and supple services to suit the requirements of consumers [25].

Enhancing the affirmation involvement with the responsiveness, reliability, empathy, assurance and tangibility the overall traditional customary services results in consumer pleasure [18]. "The study recommends that two SERVQUAL measurements (assurance and empathy) are significant affects the satisfaction" [26]. The findings of previous researches explored that empathy has significant impact on consumer satisfaction [10] [27].

\subsection{Reliability}

Reliability supports and provides the sense of responsibilities in different service sectors. For example, legitimate record upkeep, billing precision and providing the service inside satisfactory time constrain [28]. It used to provide the accurate specialized procedural facility of a self-services innovations and the exactness of service delivery [29]. Many researchers have identified that reliability emphasizes to show that how much a guaranteed benefit service provided by an e-government website will execute in the given guaranteed time, for example, sending e-mails or calling to the customer, and also giving the certainty of providing the accurate 
products and services [30]. According to Parasuraman and Yantis (1998) indicated that reliability is a standout amongst the most imperative measurements in SERVQUAL listed variables [31].

While most of the investigation regarding providing quality e-service has recognized that reliability is the most important measurements on e-service quality dimensions. While the recent investigations on e-services quality confirmed that reliability has been utilized as a part of four unique settings in 15 investigative studies on e-service quality, which affirms that reliability is a standout amongst the most significant elements that ought to be underscored in guaranteeing a decent quality. Previous studies also conclude four notable quality measurements prompting both fulfillment and disappointment, including reliability, easy to use, competence and responsiveness [22].

There are seven measurements and twenty-six items incorporating reliability which are considered as the projected level for measuring the e-service quality in the domain of e-government. These measurements have been utilized as a part of the scale since they are essential for guaranteeing consumers' satisfaction [32]. In addition, Zhu and colleagues (2002) contended that reliability measurement has a significant positive impact on apparent service quality and consumer satisfaction by service sector [33]. Recent study has featured the significance of service reliability, illustrating that transit organizations wishing to build their consumers' levels of satisfaction should concentrate on building up a reliable consistent service [34]. Wolfinbarger and colleagues (2002) discover that various dimensions of their measure of e-service quality sly affect the outcomes. They found that satisfaction and reliability is the most important predictor of consumer satisfaction [35].

\subsection{Trust}

Trust has according to Kissim and his colleagues (2003) indicate that trust is likewise an imperative factor to fabricate and sustain strong relationship between the company and their consumers, yet it is additionally considering as hard to manage [36]. Gefen and his colleagues (2003) Assumed the conceptualization of trust as a combination of particular attitude which consist predictability, integrity, ability, benevolence to be implement in e-business particularly in the web based online shopping setting [37].

Warkentin and colleagues (2002) indicate that experience impacts a customer trust of e-Government [38]. Citizen's with related knowledge, particularly if satisfy, would probably come back to utilize e-Government services. By examining web based tax facilities, a standout amongst the most broadly utilized of the online services in different countries. First, the statistical results demonstrated that the trust most emphatically influenced consumer satisfaction and over-all service quality for online stores. This systematic outcome is steady with that of Geffen (2002) who concluded that trust is a strong determinant of e-service performance that recognized trust as key drivers of consumer satisfaction and perceived 
service quality.

\subsection{E-Service Satisfaction and Intentions to Use}

Consumer initiates with understandable, equipped description from both the users and the organization. Accepting the inspirations, desires and prospect of both parties gives a ground that how to best serve the client and fulfill his/her needs. It will also enable to provide vital information which will help in improving in the nature of the business, and for the client satisfaction and organizational achievements is the considered as the central part of research proposed by Naylor and Greco, the importance of explaining the basic concepts and essentials which lead towards satisfaction neatly will give a model information regarding which function is working and which is not, which is satisfied and which is not up to the mark [39]. In the review of previous studies related to the current research, the current study found that there are a wide range of definitions for terms identified with service quality, specifically for the website service quality and online service quality.

E-service quality was presented as another concept by Zeithaml and colleagues (2002), Illustrate the notion of e-service quality, which is considered as "the degree to which a site facilitates effective and efficient shopping, delivery and purchasing of items and services" [36]. Customer fulfillment is an imperative predictor of online customer behavior and the accomplishment of an electronic service. If the users are satisfying with the service received through the online system, it is likely they will continue utilizing the system. With the intentions to revisit again, if consumers get frustrated and disappointed with the online system, they would be probably not going to return for a visit. Accomplishment is an effective condition that is the emotional reaction to an item or service experience [37].

Evanschitzky and colleagues (2004) stated that the most observable distinction amongst traditional and electronic retail service is the substitution of human-to-human communication with human-to-machine interaction and accordingly. In earlier studies various' researchers proposed different 16 measurements of measuring e-service quality, while Zeithaml (2002) developed eleven measurements [40]. Some of those elements have been contemplated by scientists to recognize the e-consumer loyalty or accomplishment of the web based trade.

Most of the e-SQ researchers demonstrate that the e-SQ is the forerunners of e-consumer satisfaction. Syymanski and Hise (2005) narrate that a positive observed service quality has positively affect consumers' intention to buy and user satisfaction [20] [41]. Moreover additionally reasoned that the productivity of e-service positively affect consumer loyalty and satisfaction [42]. Earlier researchers have shown that consumer satisfaction positively affects future repurchase intentions [43] [44]. In particular, satisfied customers will frame repurchase expectations while disappointed shoppers will cease their intentions to use 
in future as re-visit.

\section{SERVQUAL Scale for Measuring Service Quality}

E-service quality measurement has been addressed by the researchers that had attempted to find out the key dimensions of e-service quality related with online environment. These studies have been conducted in different context, including online services area, online hoteling, online shopping, online health services, online learning, online retailing, web portal [32] [45] and online travel agency as shown in Table 1 . The service quality also affects the customer relationship management in economic terms [32] [45]. The table illustrate, that these service quality dimensions has been used in web based services domain, which have been highly cited in most recent studies. The table adopted from previous studies [32] [45].

Table 1. SERVQUAL scale for measuring service quality.

\begin{tabular}{|c|c|c|}
\hline Dimensions & Country & Sector \\
\hline $\begin{array}{l}\text { Responsiveness, Empathy, Security, } \\
\text { Reliability, Tangible [46] }\end{array}$ & Jordan & Online Banking \\
\hline $\begin{array}{l}\text { Responsiveness, Empathy, Assurance, } \\
\text { Reliability, Tangible [47] }\end{array}$ & $\begin{array}{l}\text { Georgia, } \\
\text { Turkey }\end{array}$ & Internet Service Customers \\
\hline Empathy, Reliability [48] & Pakistan & Telecom Sector \\
\hline $\begin{array}{l}\text { Responsiveness, Empathy, Assurance, Reliability, } \\
\text { Tangible, Complaint Handling, Convenience, } \\
\text { Network Quality [49] }\end{array}$ & Syria & Telecommunication Services \\
\hline $\begin{array}{l}\text { Responsiveness, Assurance, } \\
\text { Reliability, Tangible [50] }\end{array}$ & Bangalore & Online hotel Industry \\
\hline $\begin{array}{l}\text { Responsiveness, Empathy, Assurance, } \\
\text { Reliability, Tangible [51] }\end{array}$ & Georgia & GSM SERVICE SECTOR \\
\hline $\begin{array}{l}\text { Responsiveness, Empathy, Security, } \\
\text { Reliability, Tangible [46] }\end{array}$ & Jordan & Online baking \\
\hline $\begin{array}{l}\text { Responsiveness, Empathy, Assurance, } \\
\text { Reliability, Tangible [26] }\end{array}$ & Turkey & Public Healthcare Industry \\
\hline $\begin{array}{l}\text { Responsiveness, Personalization Web Designs, } \\
\text { Ease Of Use, Assurance And Trust. [52] }\end{array}$ & $\begin{array}{c}\text { Malaysia } \\
\text { and Qatar }\end{array}$ & E-Commerce \\
\hline $\begin{array}{l}\text { Efficiency, Usefulness, Confidentiality, Security, } \\
\text { Ease To Use, Responsiveness. [53] }\end{array}$ & Iran & E-service \\
\hline $\begin{array}{l}\text { Web Design, Customer Service, Assurance } \\
\text { And Order Management [37] }\end{array}$ & Spain & E-commerce \\
\hline $\begin{array}{l}\text { Trust, Customized Communications, Ease Of } \\
\text { Use, Website Content And Functionality, } \\
\text { Reliability And Speed Of Delivery [54] }\end{array}$ & USA & E-financial Institutions \\
\hline $\begin{array}{l}\text { Reliability, Website Design, Security/Privacy And } \\
\text { Responsiveness [55] }\end{array}$ & USA & E-Service \\
\hline
\end{tabular}




\subsection{Research Questions}

- What are the most important e-service quality dimensions in e-taxation and how these dimensions' effect customer's satisfaction in e-taxation in Pakis$\tan$ ?

- How the e-service quality dimensions can be conceptualized and described in the case of e-taxation to measure consumer satisfaction and intentions to revisit?

\subsection{Research Conceptual Framework}

In current study four e-service quality dimensions will be used as independent variables (Responsiveness, Reliability, trust and empathy) to measure customer satisfaction and reuse intentions in e-taxation of FBRin Pakistan. These service quality dimensions are adapted from e-service previous studies responsive adopted from existing pool of studies Parasuraman [56], reliability adopted from Yang [22] and empathy and trust adopted from Madu [57]. The statistical model was employed to measure the significance, influence among independent variables (responsiveness, reliability, empathy, trust and satisfaction) as well as to measure the relationship between independent and dependent variables (satisfaction and re-use intentions) as shown in Figure 1.

This research proposes the following seven hypotheses:

Responsiveness: Responsiveness is readiness to enable consumers and give to speedy benefit. Responsiveness is probably going to have an imperative and significant influence on citizen's satisfaction [56] [58] [59]. Thus the following hypotheses are suggested.

H1: The responsiveness has significant positive influence on customer satisfaction.

H5: The responsiveness has significant positive impacts on customer reuse intentions.

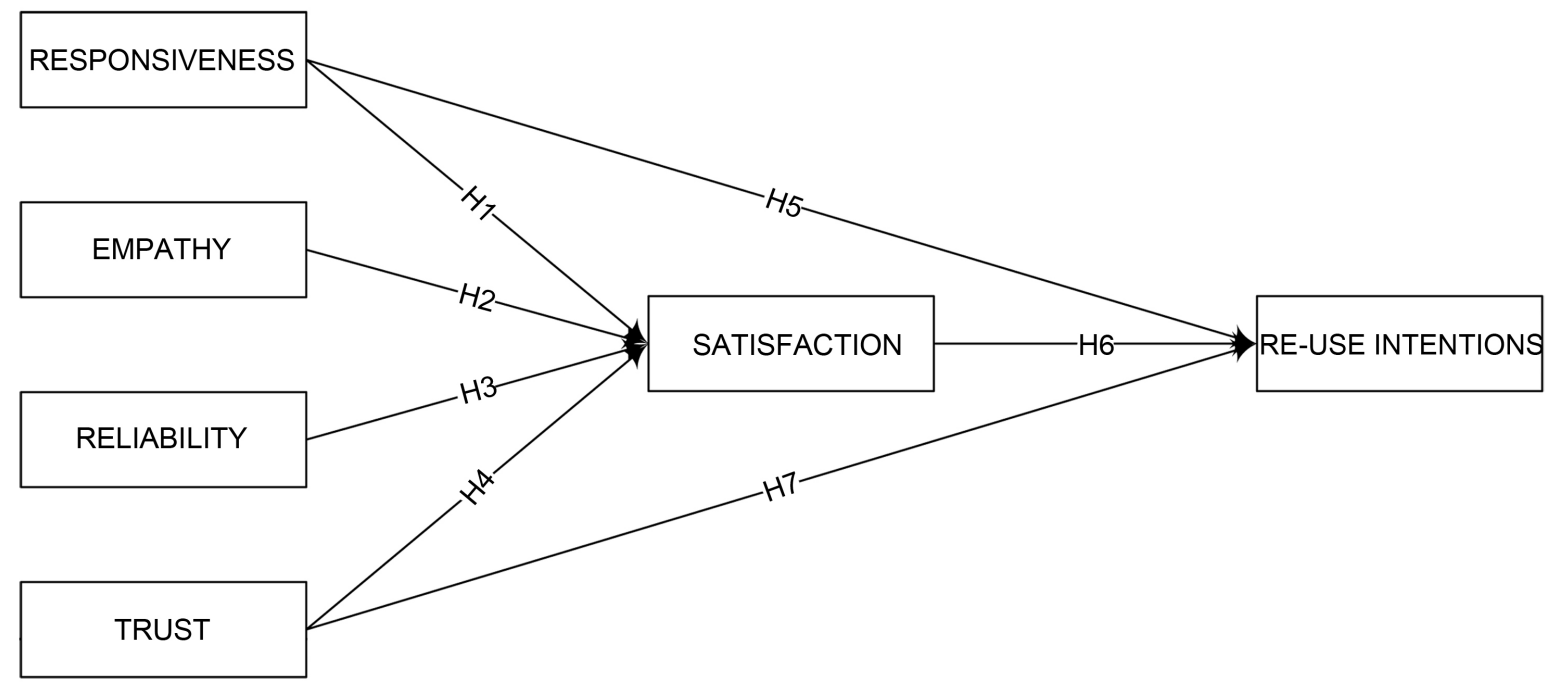

Figure 1. Conceptual model for the current study. 
Empathy: Empathy has defined to "caring, individualized attention the government provides for its citizens". Empathy is likely to have a vital and encouraging effect on citizens contentment [7] [27] [57] [60]. Consequently, the following hypotheses are suggested.

H2: The Empathy has significant positive influence over citizen's satisfaction.

Reliability. Reliability is the capacity to execute the guaranteed services in a reliable, accurate and completely mindful way, without carelessness and disappointment [61]. Reliability is probably going to have an imperative and constructive outcome on citizens satisfaction [22] [32] [62] [63]. Consequently, the following hypotheses are suggested.

H3: There is a positive association between reliability and customer satisfaction.

Trust: Trust is detailed set of believes which comprises ability, integrity, and predictability to be connected in online services [64]. Online users usually avoid electronic service providers whom they don't trust [65]. It means that It implies that trust is accepted as a vital component to building association with citizens online trust which significantly affect positive for long term relationship [52] [66]. The previous researchers indicated that trust is positively related to citizens satisfaction and intentions to use [20] [57] [67] [68]. Consequently, the following hypotheses are suggested.

H4: There is strong positive relationship between trust and customer satisfaction.

H7: The trust has significantly positive relatedness to customer Intention to use.

Satisfaction: Satisfaction is more than of service provision over customers' expectations drive by the perceptions and expectations about the given service quality. Customer satisfaction and it is significantly related to intentions to use [54] [56] [69]. Therefore, the following hypothesis is suggested.

H6: Customers reuse intention mediated by customer satisfaction toward e-service quality.

\section{Methodology}

\subsection{Research Purpose}

Every research can be categorized in context of their purpose. Accordingly, most of these are categorized study is descriptive and explanatory. The study is descriptive because the data will be collected through detailed semi-structure questionnaire and it's also exploratory because we test the relationship between e-service quality i.e. five variables (reliability, Responsiveness, trust, Empathy) with customer's satisfaction and how these e-service quality dimensions' influence customer's satisfactions. Thereby how trust, responsiveness and satisfaction mediate intention of use. Nowadays the monitoring of consumer satisfaction is considered one of most important strategic and effective quality management. The customers are based on their pervious experiences, needs and information 
acquired from the friendly environment creates the permanent and ideal customers and it also shows the expected performance of service providers. If the service is fulfilling the customer expectation it promotes customers satisfactions to higher degree [70].

\subsection{Sampling Design and Sampling}

The population of this study comprised with the registered citizens with the portal for e-filling in Pakistan. Non-probability sampling i.e. convenient sampling design used to collect the data from all participants. The semi-structure questionnaire employed as instrument of data collection because quantitative questionnaire is considered one of most reliable instrument of technology adoption as it uses a set of research questions to fulfill the data requirements of study as well to target specific numbers of respondents in more efficient and practical way [71] [72]. Finally, the sample of this study consist e-taxation users of Pakistani citizens and quantitative questionnaire will be distributed among 273 citizens purposively selected from twin cities (Islamabad, Rawalpindi) of Pakistan. In total 273 questionnaires were distributed among the respondents, and 206 were returned. After thoroughly checking 18 questionnaires were found uncompleted which eliminated.

\subsection{The Instruments of Data Collection}

The construct model based on previous studies which is discussed in existed literature, five-point likert scale will be used for each construct. All items of construct have been used in pervious researches; the adopted items will be modified to relate an e-taxation environment. The construct will be in two parts first part will describe the demographical data as well as the individual characteristics and the second part will be described the study constructs. The source of questionnaire items and well detail survey instrument is given below in this study. A pilot study conducted in twin cities (Rawalpindi, Islamabad) of Pakistan. The instruments distributed among thirty e-taxation users of FBR. The respondents of the study asked to identify any error or ambiguity in wording or formatting of the questions. Additionally, to increase the reliability and validity of constructs ten questionnaires distributed among research scholars. Moreover, the modification of the instrument items based on respondent's feedback.

\section{Data Analysis}

\subsection{Results and Analysis}

Table 2 summarized the demographical characteristics of the respondents. As shown in the table, $(88.7 \%)$ of the participants are observed male, and $(10.2 \%)$ of them are female. Moreover, the age group, the majority of the respondents are recorded between 25 - 40 (51.0\%), followed by age between $41-55$ (22.8\%), while (17.0\%) of them are between age of 25 and under. Overall (53.9\%) of them are recorded married, and (43.0\%) of the respondents are founded unmarried. 
Table 2. Demographical information of the respondents. Its concluded that the.

\begin{tabular}{cccc}
\hline Variable & Group & Frequency & Percentage \\
\hline Age & 25 and under & 32 & $17.0 \%$ \\
& Age between $25-40$ & 96 & $51.0 \%$ \\
& Age between $41-55$ & 43 & $22.8 \%$ \\
Gender & 55 and over & 17 & $9.0 \%$ \\
& Male & 148 & $88.7 \%$ \\
Marital Status & Female & 32 & $10.2 \%$ \\
& Single & 81 & $43.0 \%$ \\
Frequencies of web site use & Married & 107 & $53.9 \%$ \\
& 4 or less times a year & 129 & $68.6 \%$ \\
& 5 to 8 times a year & 37 & $19.6 \%$ \\
& 9 to 12 times a year & 17 & $9.0 \%$ \\
& 13 or more times a year & 5 & $2.6 \%$ \\
\hline
\end{tabular}

The educational level of the respondents is observed (36.1\%) who obtained bachelor's degree, $(21.8 \%)$ of the respondents are with postgraduate qualifications (e.g., masters or doctoral degree, whereas (11.1\%) of the respondents were holding intermediate degree. Furthermore, the average frequency of (68.6\%) of the respondents visiting 4 or less time in a year, or while (19.6\%) of them visiting 5 to 8 times in a year. In response of frequency of online taxation, the respondent of this study is familiar with electronic taxation payments environment of FBR, (35.6\%) of the respondents successfully completed their online filling, while $(20.9 \%)$ of the respondent's filling fully failed, (43.4\%) filling is partially failed.

It has been summarized that male respondents were recorded high sample size as compare to female respondents. It has been observed that male population is educated but due to equal gender population, so the sample size must be increase on equal gender base in future studies. Illiterate population was also not the part of this study which can also be considered in upcoming researches.

\subsection{Reliability and Validity Analysis}

The exploratory factor analysis (EFA) measures the items strength and ability to predict and explain each of the construct studied in the current analysis. In the statistical manner, the tools i.e. SPSS statistic v23 used to perform this task to examine validity of the items and its ability to predict determinants. In EFA the convergent validity is based on three indicators; 1 ), the construct reliability of each item (factor loading), 2) the reliability of every measure (CA), 3) the average variance extracted (AVE). All items of constructs have convergent validity when the combined reliability increased the standard of 0.7 and value of average variance extracted (AVE) is higher than 0.05 [73].

Table 3 summarized that the factor loadings, cronbach Alpha value, the 
composite reliability (CR) and the average variance extracted (AVE). All constructs loadings were higher than 0.7 and $t$ values show that all loadings were found significant at 0.001. All AVEs values are greater than 0.5 (specifically ranged between 0.540 to 0.729 ) as shown in the table below. Similarly, all CR values (ranged between 0.700 to 0.888 ) observed higher than 0.7 as shown in Table 3. Consequently the convergent validity of the measures is strongly supported by analysis result [73] [74]. Moreover, all Alpha values were found greater than 0.7, expect one construct other showing good reliability [75].

Table 4 below shows the descriptive analysis of study variables which indicate the descriptive outputs for the study variables has been used in this research. The table shows the mean and standard deviation values for the study variables of responsiveness, empathy, reliability, trust, satisfaction and reuse intentions. The mean values of the research variables are ranging from 2.4894 to 4.0160 , and the values for standard deviation are in the range of 0.631 to 0.767 . Correlation test was conducted to check the strength of relationship between variables. The values

Table 3. Reliability analysis for the collected data.

\begin{tabular}{llclll}
\hline \multicolumn{1}{c}{ Construct } & Items & Loadings & CA & CR & AVE \\
\hline \multirow{3}{*}{ Responsiveness } & RES1 & 0.832 & & & \\
& RES2 & 0.758 & 0.831 & 0.843 & 0.642 \\
& RES3 & 0.813 & & & \\
Empathy & EMP1 & 0.872 & 0.749 & 0.862 & 0.578 \\
& EMP2 & 0.870 & & & \\
Reliability & RLB1 & 0.819 & & & \\
& RLB2 & 0.852 & 0.858 & 0.888 & 0.726 \\
& RLB3 & 0.885 & & & \\
Trust & TRT1 & 0.824 & & & \\
& TRT2 & 0.889 & 0.857 & 0.857 & 0.668 \\
Satisfaction & TRT3 & 0.732 & & & \\
& SAT1 & 0.771 & 0.795 & 0.842 & 0.729 \\
Reuse Intentions & SAT2 & 0.930 & & & \\
& INT1 & 0.786 & 0.642 & 0.700 & 0.540 \\
\hline
\end{tabular}

Table 4. Descriptive statistics and correlation analysis.

\begin{tabular}{lcccccccc}
\hline \multicolumn{1}{c}{ Construct } & Mean & SD & RES & EMP & RLB & TRT & SAT & INT \\
\hline Responsiveness & 2.8936 & 0.73081 & 0.801 & & & & & \\
Empathy & 2.8475 & 0.75078 & 0.335 & 0.760 & & & & \\
Reliability & 2.4894 & 0.74767 & 0.183 & 0.192 & 0.852 & & & \\
Trust & 3.5585 & 0.73081 & 0.368 & 0.117 & 0.103 & 0.817 & & \\
Satisfaction & 3.8014 & 0.57440 & 0.554 & 0.285 & 0.284 & 0.246 & 0.853 & \\
Reuse Intentions & 4.0160 & 0.63122 & 0.272 & 0.192 & 0.224 & 0.276 & 0.448 & 0.734 \\
\hline
\end{tabular}

Note: The diagonal in the correlation analysis holds square-root of AVE of each construct. 
of correlation ( $\mathrm{r}$ ) given in the table indicates the supportive results for correlation among independent and dependent variables [76].

\subsection{Result of Multiple Regression of IVs on DV}

From the result of ANOVA it is conceivable to discover whether the given created model is significant and at what level. The effect of responsiveness, empathy, reliability and trust on customer satisfaction was investigated through multiple regression analysis. The regression test was conducted to measure and to predict customer satisfaction (Dependent Variable) based on (predicted variables) responsiveness (IV1), empathy (IV2), reliability (IV3) and trust (IV4). The regression value was found significant $(\mathrm{F}(4,183)=14.535, \mathrm{P}<0.000)$ with an R2 of 0.341. Participant predicted is equal to $1.676+0.042$ iv1 +0.78 iv2 +0.140 iv3 + 0.401 iv4 (responsiveness, empathy, reliability and trust) [C-Satisfaction DV measured] by satisfaction of users when [independent variables] is measured in [unit of measure].

$\mathrm{H} 1$; the statistical analysis summarized the relationship between the responsiveness towards the customer satisfaction was challenged through the collected data sample, the significant relation has proved through coefficient of $0.042(\mathrm{p}<$ $0.040, \mathrm{n}=188$ ). The result demonstrates that the responsiveness of FBR website have positive relationship with customer satisfaction.

$\mathrm{H} 2$; the recorded statistical data disclose the association between empathy toward customer satisfaction, which have negative relation with the recorded value of 0.078 as coefficient $(\mathrm{p}<0.172, \mathrm{n}=188)$. This summarized that the empathy of FBR website service has significant negative relation with customers' satisfaction.

$\mathrm{H} 3$; the table reveals that reliability creates positive impacts on customer satisfaction. An increase in reliability will bring a significant increase in customer satisfaction. It is concluded to have significant association with the recorded value of 0.140 as coefficient $(\mathrm{p}<0.011, \mathrm{n}=188)$. This indicates that the reliability of website has significant relation with customer's satisfaction.

H4; the result indicates the relationship between trust toward customer's satisfaction, it is observed to have strong association with the recorded value of 0.401 as coefficient $(\mathrm{p}<0.000, \mathrm{n}=188)$. This summarized that the trust of FBR website service quality has significant positive impacts on customer satisfaction. Overall three hypotheses of the study are proved significant and (IV134) service quality dimension have significant influence on (DV) customer satisfaction. Whereas trust is found highly significant among four DVs, as well empathy found lowest significant as shown in Table 5.

The ANOVA test has been employed to check overall fitness of the model. The whole model is significant, with $\mathrm{F}$ test value of 39.873 with $\mathrm{df} 3.184$. F test is used to exemplify overall fitness of model, here F statistics overall significance of independent variables as part of regression model. Here change in customer reuse intentions due to responsiveness, trust, customer satisfaction and trust is $\mathrm{R}^{2}$ 0.394 . Here $R^{2} 0.384$ units of change in customer reuse intentions is explained 
Table 5. Regression analysis to define satisfaction (SAT).

\begin{tabular}{ccccc}
\hline Hypo. & Detail & P Value & Beta & Result \\
\hline $\mathrm{H} 1$ & $\mathrm{RES}^{+} \rightarrow \mathrm{SAT}^{+}$ & 0.040 & 0.250 & Supported \\
$\mathrm{H} 2$ & $\mathrm{EMP}^{+} \rightarrow \mathrm{SAT}^{+}$ & 0.172 & 0.093 & Non supported \\
$\mathrm{H} 3$ & $\mathrm{RLB}^{+} \rightarrow \mathrm{SAT}^{+}$ & 0.011 & 0.171 & Supported \\
$\mathrm{H} 4$ & $\mathrm{TRT}^{+} \rightarrow \mathrm{SAT}^{+}$ & 0.000 & 0.365 & Supported \\
\hline
\end{tabular}

i.e. responsiveness, trust and customer satisfaction. Results are shown in Table 6.

The regression test was conducted to measure the relationship between study variables and to predict customer reuse intentions (Dependent Variable) based on (predicted variables) responsiveness (IV1), Trust (IV2) and customer satisfaction (IV3). The regression value was found significant $(\mathrm{F}(3,184)=39.873, \mathrm{P}<$ $0.000)$ with an R2 of 0.695 . Participant predicted is equal to $0.560+0.176$ iv1 + 0.226 iv2 + 0.564 iv3 (responsiveness, trust, customer satisfaction) [customer reuse intentions DV measured] by satisfaction of customers when [independent study variables] is measured in [unit of measure].

$\mathrm{H} 5$; the statistical date concluded the association between responsiveness toward customer reuse intentions which recorded positive association through coefficient vales is $0.176(\mathrm{p}<0.03 \mathrm{n}=188)$. It's observed that responsiveness has positive impacts on customer reuse intentions.

H6; was challenging the association between trust towards customer reuse intentions. The coefficient values 0.226 ( $\mathrm{p}<0.000, \mathrm{n}=188$ ) has proved positive relations between study variables. This is indicated that the trust is second influential factor which has positive impacts on customer's reuse intentions.

$\mathrm{H7}$; the statistical data indicate the influence of customer satisfaction towards customer reuse intentions, the significant positive impacts have observed through coefficient values is 0.564 ( $\mathrm{p}<0.000, \mathrm{n}=188$ ). It's observed that customer satisfaction has positive influence over customer reuse intentions. Thus it can be concluded on the base of statistical data that all IVs (responsiveness, trust and customer satisfaction) have positive influence on ID (customer reuse intentions). Whereas satisfaction is found highly significant among three DVs, as well responsiveness found lowest significant.

\section{Results and Discussion}

The research illustrates inter relationship of service quality dimensions (responsiveness, trust, reliability and empathy) and its impacts on customer satisfaction as well on customer reuse intentions in e-taxation of federal board of revenue in Pakistan. Therefore, these four service quality dimensions have significant relationship with customer satisfaction on the other hand two dimensions of service quality and customer satisfaction has recorded significant influence on customer reuse intentions.

This study also observed that service quality dimension is appropriate tool to measure the quality of e-taxation service quality in Pakistan. So the concerned 
Table 6. Regression analysis to define reuse intentions (INT).

\begin{tabular}{ccccc}
\hline Hypo. & Detail & P Value & Beta & Result \\
\hline $\mathrm{H} 5$ & $\mathrm{RES}^{+} \rightarrow \mathrm{INT}^{+}$ & 0.003 & 0.181 & Supported \\
$\mathrm{H} 6$ & $\mathrm{TRT}^{+} \rightarrow \mathrm{INT}^{+}$ & 0.000 & 0.238 & Supported \\
$\mathrm{H} 7$ & $\mathrm{SAT}^{+} \rightarrow \mathrm{INT}^{+}$ & 0.000 & 0.444 & Supported \\
\hline
\end{tabular}

authorities of the relevant institutions can use this tool to evaluate the e-taxation service quality in all regions especially in metropolitan cities of Pakistan. Service quality should be focused to improve and maintain customer satisfaction as well as it should have positive impacts on customer reuse intentions.

Among the four dimensions of service quality responsiveness, empathy, reliability and trust observed the important predicator of customer satisfaction furthermore two dimensions of service quality and customer satisfaction has found significant predicator of customer reuse intensions. This implies that these four dimensions of service quality and customer satisfaction are most important for the users of e-taxation in Pakistan.

The study summarized with the result that customer satisfaction and customer reuse intentions in e-taxation services of Pakistan has significantly affected by responsiveness, empathy, reliability and trust.

The study found that $\mathrm{H} 1$ is supported in this study with beta value of 0.250 for responsiveness by past studies i.e. in the Telecommunication Services industry in the context of Syria [49], in a Public Healthcare Industry in the context of Turkey [26], in an online banking services of Jordan [46] [77], in an Internet Service Customers [47], in a GSM service sector of Georgia [51], in an online Hotel Industry of Bangalore [50] observed that the higher level of responsiveness apparently foster customer satisfaction.

Moreover, reliability and empathy have interesting impact on consumer satisfaction. As $\mathrm{H} 2$ observed to be insignificant in the current study with beta values of 0.093 . Whereas, H3 supported in this research with beta value of 0.171 for reliability against consumer satisfaction. Therefore the empirical results of this research are strongly suggested by supporting studies [26] [46]-[51]. The empirical findings of these previous studies have indicated that empathy and reliability play most important role in enhancing customer satisfaction in various online service industries in context of different countries.

Additionally, when compared, independent variables of responsiveness, empathy and reliability have a significant positive influence on customer satisfaction towards e-taxation services.

Thus H5, H6 and H7 are strongly supported in this study, which have significant positive influence on customer reuse intentions towards e-taxations services of Pakistan. The beta values of 0.181 for responsiveness, 0.238 for trust and 0.444 for customer satisfaction against customers' reuse intentions. The empirical findings of previous studies supported the significant influence of (responsiveness, trust and customer satisfaction) IDs on DP (customer reuse intentions). 


\section{Conclusion}

This research elaborated that service quality dimension's holds strong impacts on customer satisfaction and customer reuse intentions. The current study observed that there are positive relations among independent and dependent variables of the current study. Despite the fact that consumer service has been assessed long time prior, it's still one of imperative research that e-government services must keep on conducting with a specific end goal to meet the suitable changes in the service quality which can develop tax payers' satisfaction and prompt e-users reuse intentions. New technologies must be integrated as a factor to assess service quality in upcoming future studies. A clearer understanding with regards to the arrangement of connection between service qualities, consumer satisfaction can guarantee better focusing of customer reuse intentions. SERVQUAL scale for measuring service quality to contextualize e-service quality, an examination of the SERVQUAL scale is required since a large portion of the present e-service quality scales are developing in light of the SERVQUAL instrument.

\section{Limitation and Future Studies}

The current study has several limitations and the most important is the sample size. The validity of the result might be less because of small sample size. The respondent of this research were mainly selected from two metropolitan cities (Islamabad and Rawalpindi) whereas future studies are advised to increase the sample size. The study should focus on other cities of Pakistan to enhance the level of validity and generalization. Another limitation of this research is questionnaire language which was in English. Most of the respondents who are not familiar with the English might not thoroughly understand the given items in the survey instrument, which could enhance the confusions in the given questions that might affect reliability of data set. There for future studies are suggested to include local languages such as Urdu, Punjabi and Pashto in the survey instrument to be appropriate for the respondents. The last limitation, this study only selected several appropriate service quality dimensions as an independent and dependent variables related to the issue which doesn't cover all dimensions of e-service quality. Additionally, the future studies are suggested to expand the number of e-service quality dimensions which could lead to improve validity and to predict customer satisfaction as well as reuse intention in various e-services domain.

\section{References}

[1] Teicher, J., Hughes, O. and Dow, N. (2002) E-Government: A New Route to Public Sector Quality. Managing Service Quality: An International Journal, 12, 384-393. https://doi.org/10.1108/09604520210451867

[2] Hazlett, S.-A. and Hill, F. (2003) E-Government: The Realities of Using IT to Transform the Public Sector. Managing Service Quality: An International Journal, 13, 445-452. https://doi.org/10.1108/09604520310506504 
[3] Li, H., Liu, Y. and Suomi, R. (2009) Measurement of E-Service Quality: An Empirical Study on Online Travel Service. 1-13.

[4] Kim, D.J., Ferrin, D.L. and Rao, H.R. (2009) Trust and Satisfaction, Two Stepping Stones for Successful E-Commerce Relationships: A Longitudinal Exploration. Information Systems Research, 20, 237-257. https://doi.org/10.1287/isre.1080.0188

[5] Barnes, S.J. and Vidgen, R.T. (2002) Assessing E-Commerce Quality with WebQual: An Evaluation of the Usability, Information Quality, and Interaction Quality of Internet Bookstores. Journal of Electronic Commerce Research, 3, 114-127.

[6] Collier, J.E. and Bienstock, C.C. (2006) Measuring Service Quality in E-Retailing. Journal of Service Research, 8, 260-275. https://doi.org/10.1177/1094670505278867

[7] Li, H. and Suomi, R. (2009) A Proposed Scale for Measuring E-Service Quality. International Journal of $U$ - and E-Service, Science and Technology, 2, 1-10.

[8] Gilbert, D., Balestrini, P. and Littleboy, D. (2004) Barriers and Benefits in the Adoption of E-Government. International Journal of Public Sector Management, 17, 286-301. https://doi.org/10.1108/09513550410539794

[9] Tan, C.W., Benbasat, I. and Cenfetelli, R.T. (2008) Building Citizen Trust towards E-Government Services: Do High Quality Websites Matter? 217.

[10] Kheng, L.L., Mahamad, O., Ramayah, T., et al. (2010) The Impact of Service Quality on Customer Loyalty: A Study of Banks in Penang, Malaysia. International Journal of Marketing Studies, 2, 57-66. https://doi.org/10.5539/ijms.v2n2p57

[11] Hansen, E. and Jonsson, E. (2013) E-Loyalty in Fashion E-Commerce: An Investigation in How to Create E-Loyalty. 64-91.

[12] Chang, H.H., Wang, Y.-H. and Yang, W.-Y. (2009) The Impact of E-Service Quality, Customer Satisfaction and Loyalty on E-Marketing: Moderating Effect of Perceived Value. Total Quality Management, 20, 423-443. https://doi.org/10.1080/14783360902781923

[13] Portela, M.C.A.S. and Thanassoulis, E. (2005) Profitability of a Sample of Portuguese Bank Branches and Its Decomposition into Technical and Allocative Components. European Journal of Operational Research, 162, 850-866.

[14] Caruana, A. (2002) Service Loyalty: The Effects of Service Quality and the Mediating Role of Customer Satisfaction. European Journal of Marketing, 36, 811-828. https://doi.org/10.1108/03090560210430818

[15] Masood, A. (21017) E-Filing of Tax in Pakistan. 1-3.

[16] Connolly, R. and Bannister, F. (2008) eTax Filing \& Service Quality: The Case of the Revenue Online Service. Proceedings of World Academy of Science. Engineering and Technology, 28, 313-317.

[17] Kim, M., Kim, J.-H. and Lennon, S.J. (2006) Online Service Attributes Available on Apparel Retail Web Sites: An ES-QUAL Approach. Managing Service Quality: An International Journal, 16, 51-77. https://doi.org/10.1108/09604520610639964

[18] Parasuraman, A., Zeithaml, V.A. and Berry, L.L. (1988) Servqual: A Multiple-Item Scale for Measuring Consumer Perc. Journal of Retailing, 64, 12.

[19] Fan, W.-S. and Tsai, M.-C. (2010) Factors Driving Website Success-The Key Role of Internet Customisation and the Influence of Website Design Quality and Internet Marketing Strategy. Total Quality Management, 21, 1141-1159. https://doi.org/10.1080/14783363.2010.529335

[20] Lee, G.-G. and Lin, H.-F. (2005) Customer Perceptions of E-Service Quality in Online Shopping. International Journal of Retail \& Distribution Management, 33, 161-176. https://doi.org/10.1108/09590550510581485 
[21] Ribbink, D., Van Riel, A.C., Liljander, V., et al. (2004) Comfort Your Online Customer: Quality, Trust and Loyalty on the Internet. Managing Service Quality: An International Journal, 14, 446-456. https://doi.org/10.1108/09604520410569784

[22] Yang, Z. and Fang, X. (2004) Online Service Quality Dimensions and Their Relationships with Satisfaction: A Content Analysis of Customer Reviews of Securities Brokerage Services. International Journal of Service Industry Management, 15, 302-326. https://doi.org/10.1108/09564230410540953

[23] Parasuraman, A., Zeithaml, V.A. and Berry, L.L. (1985) A Conceptual Model of Service Quality and Its Implications for Future Research. The Journal of Marketing, 49, 41-50. https://doi.org/10.2307/1251430

[24] Ananth, A., Ramesh, R. and Prabaharan, B. (2010) Service Quality Gap Analysis in Private Sector Bank-A Customer Perspective. Indian Journal of Commerce and Management Studies, 2, 245-252.

[25] Ndubisi, N.O. (2006) A Structural Equation Modelling of the Antecedents of Relationship Quality in the Malaysia Banking Sector. Journal of Financial Services Marketing, 11, 131-141. https://doi.org/10.1057/palgrave.fsm.4760033

[26] Kitapci, O., Akdogan, C. and Dortyol, İ.T. (2014) The Impact of Service Quality Dimensions on Patient Satisfaction, Repurchase Intentions and Word-of-Mouth Communication in the Public Healthcare Industry. Procedia-Social and Behavioral Sciences, 148, 161-169.

[27] El Saghier, N. and Nathan, D. (2013) Service Quality Dimensions and Customers' Satisfactions of Banks in Egypt. 4-5.

[28] Saha, P. and Zhao, Y. (2005) Relationship between Online Service Quality and Customer Satisfaction: A Study in Internet Banking. Master Thesis, Luleå University of Technology, Sweden.

[29] Weijters, B., Rangarajan, D., Falk, T., et al. (2007) Determinants and Outcomes of Customers' Use of Self-Service Technology in a Retail Setting. Journal of Service Research, 10, 3-21. https://doi.org/10.1177/1094670507302990

[30] Papadomichelaki, X. and Mentzas, G. (2012) E-GovQual: A Multiple-Item Scale for Assessing E-Government Service Quality. Government Information Quarterly, 29, 98-109.

[31] Parasuraman, R. and Yantis, S. (1998) The Attentive Brain. MIT Press, Cambridge.

[32] Alanezi, M.A., Kamil, A. and Basri, S. (2010) A Proposed Instrument Dimensions for Measuring E-Government Service Quality. International Journal of $U$ - and E-Service, Science and Technology, 3, 1-18.

[33] Zhu, F.X., Wymer, W. and Chen, I. (2002) IT-Based Services and Service Quality in Consumer Banking. International Journal of Service Industry Management, 13, 69-90. https://doi.org/10.1108/09564230210421164

[34] Chakrabarti, S. and Giuliano, G. (2015) Does Service Reliability Determine Transit Patronage? Insights from the Los Angeles Metro Bus System. Transport Policy, 42, 12-20.

[35] Wolfinbarger, M. and Gilly, M.C. (2003) eTailQ: Dimensionalizing, Measuring and Predicting Etail Quality. Journal of Retailing, 79, 183-198.

[36] Zeithaml, V.A., Parasuraman, A. and Malhotra, A. (2002) Service Quality Delivery through Web Sites: A Critical Review of Extant Knowledge. Journal of the Academy of Marketing Science, 30, 362-375. https://doi.org/10.1177/009207002236911

[37] Cristobal, E., Flavián, C. and Guinaliu, M. (2007) Perceived E-Service Quality (PeSQ) Measurement Validation and Effects on Consumer Satisfaction and Web Site Loyalty. Managing Service Quality: An International Journal, 17, 317-340. 
https://doi.org/10.1108/09604520710744326

[38] Warkentin, M., Gefen, D., Pavlou, P.A., et al. (2002) Encouraging Citizen Adoption of E-Government by Building Trust. Electronic Markets, 12, 157-162. https://doi.org/10.1080/101967802320245929

[39] Naylor, M. and Greco, S. (2002) Customer Chemistry: How to Keep the Customers You Want and Say “Good-Bye” to the Ones You Don't. McGraw Hill Professional, 29-66.

[40] Zeithaml, V.A. (2002) Service Excellence in Electronic Channels. Managing Service Quality: An International Journal, 12, 135-139. https://doi.org/10.1108/09604520210429187

[41] Szymanski, D.M. and Hise, R.T. (2000) E-Satisfaction: An Initial Examination. Journal of Retailing, 76, 309-322.

[42] Fakhri, G., Menacere, K. and Pegum, R. (2009) The Impact of Contingent Factors on the Use of Performance Measurement System in the Banking Industry: The Case of Libya. 45.

[43] Bitner, M.J. (1990) Evaluating Service Encounters: The Effects of Physical Surroundings and Employee Responses. The Journal of Marketing, 54, 69-82. https://doi.org/10.2307/1251871

[44] Mohsan, F., Nawaz, M.M., Khan, M.S., et al. (2011) Impact of Customer Satisfaction on Customer Loyalty and Intentions to Switch: Evidence from Banking Sector of Pakistan. International Journal of Business and Social Science, 2, 16.

[45] Swaid, S.I. and Wigand, R.T. (2009) Measuring the Quality of E-Service: Scale Development and Initial Validation. Journal of Electronic Commerce Research, 10, 13.

[46] Al-Azzam, A.F.M. (2015) The Impact of Service Quality Dimensions on Customer Satisfaction: A Field Study of Arab Bank in Irbid City Jordan. European Journal of Business and Management, 7, 45-54.

[47] Aydinli, C. and Kiliç, Ş. (2015) Impact of Service Quality Dimensions on Satisfaction and Loyalty: A Cross-National Research on Internet Service Customers. Journal of Social Sciences Research, 9, 1920-1928.

[48] Arslan, M., Iftikhar, M. and Zaman, R. (2014) Effect of Service Quality Dimensions on Customer Satisfaction: A Comparative Analysis of Pakistan Telecom Sector. Revista de Management Comparat International, 15, 440.

https://doi.org/10.2139/ssrn.2515046

[49] Rahhal, W. (2015) The Effects of Service Quality Dimensions on Customer Satisfaction: An Empirical Investigation in Syrian Mobile Telecommunication Services. International Journal of Business and Management Invention, 4, 81-89.

[50] Rao, P.S. and Sahu, P.C. (2013) Impact of Service Quality on Customer Satisfaction in Hotel Industry. IOSR Journal of Humanities and Social Science, 18, 39-44. https://doi.org/10.9790/0837-1853944

[51] Demir, A., Eray, O. and Erguvan, M.M. (2015) How Non-Technical Dimensions of Service Quality Effects Satisfaction and Loyalty of Costomers at GSM Service Sector in Georgia? International Journal of Engineering Technology and Scientific Innovation, 1, 150-162.

[52] Kassim, N. and Asiah Abdullah, N. (2010) The Effect of Perceived Service Quality Dimensions on Customer Satisfaction, Trust, and Loyalty in E-Commerce Settings: A Cross Cultural Analysis. Asia Pacific Journal of Marketing and Logistics, 22, 351-371. https://doi.org/10.1108/13555851011062269 
[53] Bagheri, S.S. (2016) Evaluation of E-Services from the Viewpoint of Insurance Clients in Iran Using Ahp and Extended Topsis Based on Possibility Theory (Case Study: Iran, Asia, Sina, Mihan, Dana and Razi Insurance Agencies). International Business Management, 10, 5695-5704.

[54] Sohn, C. and Tadisina, S.K. (2008) Development of E-Service Quality Measure for Internet-Based Financial Institutions. Total Quality Management, 19, 903-918. https://doi.org/10.1080/14783360802224412

[55] Kim, J., Jin, B. and Swinney, J.L. (2009) The Role of Etail Quality, E-Satisfaction and E-Trust in Online Loyalty Development Process. Journal of Retailing and Consumer Services, 16, 239-247.

[56] Parasuraman, A., Zeithaml, V.A. and Malhotra, A. (2005) ES-QUAL a Multiple-Item Scale for Assessing Electronic Service Quality. Journal of Service Research, 7, 213-233. https://doi.org/10.1177/1094670504271156

[57] Madu, C.N. and Madu, A.A. (2002) Dimensions of E-Quality. International Journal of Quality \& Reliability Management, 19, 246-258. https://doi.org/10.1108/02656710210415668

[58] Sigala, M., Christou, E., Glaveli, N., et al. (2006) Bank Service Quality: Evidence from Five Balkan Countries. Managing Service Quality: An International Journal, 16, 380-394. https://doi.org/10.1108/09604520610675711

[59] Joseph, M., Sekhon, Y., Stone, G., et al. (2005) An Exploratory Study on the Use of Banking Technology in the UK: A Ranking of Importance of Selected Technology on Consumer Perception of Service Delivery Performance. International Journal of Bank Marketing, 23, 397-413. https://doi.org/10.1108/02652320510612474

[60] Loke, S.-P., Taiwo, A.A., Salim, H.M., et al. (2011) Service Quality and Customer Satisfaction in a Telecommunication Service Provider. International Proceedings of Economics Development \& Research, 11, 24-29.

[61] An, M. and Noh, Y. (2009) Airline Customer Satisfaction and Loyalty: Impact of In-Flight Service Quality. Service Business, 3, 293-307. https://doi.org/10.1007/s11628-009-0068-4

[62] Hussain, R., Al Nasser, A. and Hussain, Y.K. (2015) Service Quality and Customer Satisfaction of a UAE-Based Airline: An Empirical Investigation. Journal of Air Transport Management, 42, 167-175.

[63] Shi, Y., Prentice, C. and He, W. (2014) Linking Service Quality, Customer Satisfaction and Loyalty in Casinos, Does Membership Matter? International Journal of Hospitality Management, 40, 81-91.

[64] Gefen, D., Karahanna, E. and Straub, D.W. (2003) Trust and TAM in Online Shopping: An Integrated Model. MIS Quarterly, 27, 51-90.

[65] Reichheld, F.F. and Schefter, P. (2000) E-Loyalty: Your Secret Weapon on the Web. Harvard Business Review, 78, 105-113.

[66] Corbitt, B.J., Thanasankit, T. and Yi, H. (2003) Trust and E-Commerce: A Study of Consumer Perceptions. Electronic Commerce Research and Applications, 2, 203-215.

[67] Al-Faouri, A.H. and Al-Kasasbeh, M.M. (2011) The Influence of Aviation Companies' Perceived Websites Quality on E-Trust: An Exploratory Study. International Journal of A viation Technology, Engineering and Management, 1, 14-29. https://doi.org/10.4018/ijatem.2011010102

[68] Feeney, M.K. and Welch, E.W. (2016) Technology-Task Coupling: Exploring Social Media Use and Managerial Perceptions of E-Government. The American Review of Public Administration, 46, 162-179. https://doi.org/10.1177/0275074014547413 
[69] Su, L., Swanson, S.R. and Chen, X. (2015) Social Responsibility and Reputation Influences on the Intentions of Chinese Huitang Village Tourists: Mediating Effects of Satisfaction with Lodging Providers. International Journal of Contemporary Hospitality Management, 27, 1750-1771. https://doi.org/10.1108/IJCHM-06-2014-0305

[70] Adamska, M. and Minárová, M. (2014) Role of Learning Organization in Building Consumer Confidence. E+ M Ekonomie a Management, 1, 62 . https://doi.org/10.15240/tul/001/2014-1-005

[71] Venkatesh, V., Morris, M.G., Davis, G.B., et al. (2003) User Acceptance of Information Technology: Toward a Unified View. MIS Quarterly, 27, 425-478.

[72] Reddick, C.G. (2005) Citizen Interaction with E-Government: From the Streets to Servers? Government Information Quarterly, 22, 38-57.

[73] Hair, J., Black, W.C., Babin, B.J., Anderson, R.E. and Tatham, R.L. (2006) Multivariate Data Analysis. 7th Edition.

[74] Gefen, D., Straub, D. and Boudreau, M.-C. (2000) Structural Equation Modeling and Regression: Guidelines for Research Practice. Communications of the Association for Information Systems, 4, 7.

[75] Nunnally, J. and Bernstein, I.H. (1994) Psychometric Theory. 3rd Edition, McGraw-Hill, New York.

[76] MacLane, S. (2012) Homology. Springer Science \& Business Media, 31-37.

[77] Okeke, T., Ezeh, G. and Ugochukwu, N. (2015) Service Quality Dimensions and Customer Satisfaction with Online Services of Nigerian Banks. The Journal of Internet Banking and Commerce, 20, 3.

\section{Submit or recommend next manuscript to SCIRP and we will provide best service for you:}

Accepting pre-submission inquiries through Email, Facebook, LinkedIn, Twitter, etc. A wide selection of journals (inclusive of 9 subjects, more than 200 journals)

Providing 24-hour high-quality service

User-friendly online submission system

Fair and swift peer-review system

Efficient typesetting and proofreading procedure

Display of the result of downloads and visits, as well as the number of cited articles

Maximum dissemination of your research work

Submit your manuscript at: http://papersubmission.scirp.org/

Or contact jss@scirp.org 